\section{Effects of Ethephon on Stock Plant Management of Coreopsis verticillata, Dianthus caryophyllus, and Veronica longifolia}

\author{
Janelle E. Glady ${ }^{1}$, N. Suzanne Lang ${ }^{2}$, and Erik S. Runkle ${ }^{2,3}$ \\ Department of Horticulture, Michigan State University, A288 Plant and \\ Soil Science Building, East Lansing, MI 48824
}

Additional index words. cuttings, flowering, plant growth regulator, speedwell, stem extension, tickseed

\begin{abstract}
Some day-neutral herbaceous perennial species can be difficult to manage as vegetative stock plants because they initiate floral buds under most environmental conditions. Although flowering of many long-day plants can be inhibited by maintaining plants under short days, extension growth is often suppressed, which makes cuttings difficult to harvest. Ethephon (2-chloroethylphosphonic acid) is an ethylene-releasing chemical used to abort flowers, inhibit internode elongation, and promote branching of floriculture crops. The objective of this research was to determine whether ethephon is effective at maintaining vegetative growth and increasing the number of cuttings harvested for three popular perennial species that are difficult to maintain as vegetative plants. Spray applications of ethephon were applied for 10 weeks biweekly (every 2 weeks) or weekly at $0,400,600$, or $800 \mathrm{mg} \cdot \mathrm{L}^{-1}$. Biweekly applications at $600 \mathrm{mg} \cdot \mathrm{L}^{-1}$ or weekly applications at $400 \mathrm{mg} \cdot \mathrm{L}^{-1}$ increased branching and the number of vegetative cuttings in Coreopsis verticillata L. 'Moonbeam' and Veronica longifolia L. 'Sunny Border Blue', respectively. Ethephon application increased branching in Dianthus caryophyllus L. 'Cinnamon Red Hots', inhibited leaf expansion and stem extension, but did not abort flowers, and induced marginal leaf necrosis at all concentrations tested. Therefore, ethephon application has potential to maintain vegetative stock plants of C. verticillata 'Moonbeam' and $V$. longifolia 'Sunny Border Blue' but not D. caryophyllus 'Cinnamon Red Hots'.
\end{abstract}

The management of herbaceous perennial species as stock plants for asexual propagation can be economically beneficial to commercial growers. Uniform vegetative growth and production of numerous shoots for cuttings are ideal qualities for stock plants. To accomplish both growth responses, environmental conditions that induce flowering (e.g., photoperiod or low temperature) must be avoided to inhibit flower induction and promote vegetative growth. Unfortunately, the ability to maintain vegetative growth is a challenge when flowering is not environmentally controlled. For example, Salvia nemorosa L. 'May Night' initiates flowers under most environmental conditions, making asexual propagation difficult (unpublished data). Another example is Dianthus caryophyllus 'Cinnamon Red Hots', which is a day-neutral plant that perpetually develops

\footnotetext{
Received for publication 19 Sept. 2006. Accepted for publication 23 Jan. 2007.

We gratefully acknowledge funding by Four Star Greenhouses, Inc., and greenhouse growers providing support for Michigan State University floriculture research.

${ }^{1}$ Graduate student.

${ }^{2}$ Associate Professor.

${ }^{3}$ To whom reprint requests should be addressed; e-mail runkleer@msu.edu.
}

flowers under most environmental conditions (Bunt and Cockshull, 1985). In contrast, other perennial plants such as Coreopsis verticillata 'Moonbeam' do not require a cold treatment but are obligate long-day plants that flower when the photoperiod is at least $14 \mathrm{~h}$ or when a 4-h light break interrupts a long night (Hamaker et al., 2000; Runkle et al., 1998). Although obligate long-day plants remain vegetative under short days, extension growth is also usually inhibited, making cutting production problematic and commercially impractical.

The inability to regulate plant growth and development using environmental signals in some species has led to attempts to chemically control these processes. The plant growth regulator ethephon, which releases ethylene, is used in the floriculture industry to manage herbaceous cuttings, stock plants, and potted crops to inhibit reproductive bud (RB) development, inhibit internode elongation, and stimulate branching. By controlling these plant responses, ethephon has become popular for its ability to streamline crop production schedules in several annual bedding plant crops, including ivy geranium [Pelargonium peltatum (L.) L'Hérit.], New Guinea impatiens (Impatiens hawkeri Bull.), and Fuchsia hybrids (Hamrick, 2003; Whitman et al., 2000). Application of ethephon can eliminate hand removal of flowers, promote and main- tain vegetative growth, and reduce labor by an estimated 80\% (Konjoian, 1994a). Unfortunately, ethylene does not interact with all species to initiate flower abortion or uniform internode elongation; thus, species-dependent reactions must be investigated.

The objective of this research was to investigate the use of ethephon as a tool to maintain stock plants for perennial species that cannot be otherwise maintained in a vegetative state using environmental manipulation such as photoperiod and chilling. In addition, we tested the hypothesis that ethephon application would increase the number of cuttings harvested, cutting quality, and rooting ability of the cuttings.

\section{Materials and Methods}

Plant material and culture. A complete list of plant species and sizes of young plants received from commercial propagators is presented in Table 1. After $3 \mathrm{~d}$ of quarantine to inspect and administer prophylactic treatment for potential pest and disease problems, plants were transplanted and placed directly into treatments. All plugs were transplanted to $13-\mathrm{cm}$ square containers (1.1-L) filled with a peat and perlite soil mix (Suremix Perlite; Michigan Grower Products, Galesburg, MI; $70 \%$ peatmoss, $21 \%$ perlite, $9 \%$ vermiculite). Plants were irrigated as necessary with reverse osmosis water supplemented with water-soluble fertilizer to provide the following $\left(\mathrm{mg} \cdot \mathrm{L}^{-1}\right): 125 \mathrm{~N}, 12 \mathrm{P}, 100 \mathrm{~K}, 65 \mathrm{Ca}, 12$ $\mathrm{Mg}, 1.0 \mathrm{Fe}$ and $\mathrm{Cu}, 0.5 \mathrm{Mn}$ and $\mathrm{Zn}, 0.3 \mathrm{~B}$, and $0.1 \mathrm{Mo}$.

Cold treatment. An additional set of Veronica longifolia 'Sunny Border Blue' plugs was transplanted into $13-\mathrm{cm}$ square plastic containers (1.1-L) containing the commercial medium previously described and placed in a cooler at $5{ }^{\circ} \mathrm{C}$ lighted from 0800 to $1700 \mathrm{HR}$ by cool-white fluorescent lamps (F96T 12/CW/VHO; Phillips, Somerset, NJ) for 8 weeks. The photosynthetic photon flux from the lamps was $\approx 10$ $\mu \mathrm{mol} \cdot \mathrm{m}^{-2} \cdot \mathrm{s}^{-1}$ at plant height. Plants were watered as needed. After this cold treatment, plants were transferred to the same greenhouse benches and environment as noncooled plants and grown for 4 weeks before the first ethephon application (11 May 2003).

Ethephon treatments. Ten plants of each species were randomly assigned to greenhouse benches in each repetition and were treated with ethephon (Florel; Monterey Chemical, Fresno, CA) spray applications at $0 \mathrm{mg} \cdot \mathrm{L}^{-1}$ (control), $400 \mathrm{mg} \cdot \mathrm{L}^{-1}\left(10.3 \mathrm{~mL} \cdot \mathrm{L}^{-1}\right)$ weekly and biweekly, and $800 \mathrm{mg} \cdot \mathrm{L}^{-1}(20.5$ $\left.\mathrm{mL} \cdot \mathrm{L}^{-1}\right)$ weekly and biweekly $(\mathrm{n}=50$ plants per species). Additional treatments of $0 \mathrm{mg} \cdot \mathrm{L}^{-1}$ ethephon (water spray) and 600 $\mathrm{mg} \cdot \mathrm{L}^{-1}\left(15.4 \mathrm{~mL} \cdot \mathrm{L}^{-1}\right)$ weekly and biweekly were applied during year $2(\mathrm{n}=80$ plants per species). No surfactants were added to the spray solutions. Ethephon was applied during the late afternoon (1600 HR) with a handpump sprayer to wet foliage and stems of all plants uniformly (solution $\approx 2 \mathrm{~L} \cdot 10 \mathrm{~m}^{-2}$ of bench space). 
Greenhouse temperature control. Plants were grown in a glass greenhouse section set at $20{ }^{\circ} \mathrm{C}$. Temperatures on each bench were measured by a thermocouple in an aspirated tube every $10 \mathrm{~s}$ and hourly averages were recorded by a CR-10 data logger (Campbell Scientific, Logan, UT). Average daily light integral (DLI) was calculated using line quantum sensors containing 10 photodiodes every $10 \mathrm{~s}$ (Apogee Instruments, Logan, UT).

Cutting harvest. Time of cutting harvest was determined when Coreopsis and Veronica had three and two nodes available per cutting, respectively, and when each plant had enough vegetative growth to take cuttings without removing more than $50 \%$ to $60 \%$ of total photosynthetic leaf area. Basal portions of each cutting were dipped in a solution of liquid auxin at $1500 \mathrm{mg} \cdot \mathrm{L}^{-1}$ (Dip'n Grow; Astoria-Pacific, Clackamas, OR) and propagated in 72-cell (0.04-L) plug trays (Landmark Plastic Corp., Akron, OH) in a 50\% commercial peat and perlite soil mix (Suremix Perlite) and 50\% perlite (Therm-O-Rock, East, New Eagle, PA) mix. Plug trays were propagated under natural photoperiods in a mist house with air temperature set at $23{ }^{\circ} \mathrm{C}$. Cuttings were rooted for 2 or 3 weeks before cutting quality was assessed. Cuttings taken at the same intervals but not used in propagation were placed into individual paper bags, labeled, and transferred to a forced-air dryer oven maintained at $60{ }^{\circ} \mathrm{C}$ for $\approx 3 \mathrm{~d}$ before dry weights (DWs) were recorded.

Data collection and analysis. Development of the experimental design during Year 2 (2003) was based on results from Year 1 (2002) to yield better information on the impact of ethephon as a tool to maintain perennial stock plants for commercial production systems. Plants were held in a glass greenhouse under 11-h photoperiods and maintained at $20{ }^{\circ} \mathrm{C}$ for 4 weeks before the first ethephon application, which began 18 Mar. 2003. Shoot length (SL), number of primary shoots (PS) (greater than $1.0 \mathrm{~cm}$ in length), and the number of RB per plant were recorded weekly for 10 weeks. The number of vegetative cuttings (VC), number of cuttings with floral buds (reproductive cuttings [RC]), and cutting DW were recorded at each cutting harvest event. The total number of cuttings per treatment was then calculated. Cutting quality was observed 2 (Coreopsis) or 3 (Veronica) weeks after propagation, and ratings were assigned according to cutting height, number of floral buds per cutting, and rooting by using a scale from 1 (poor) to 6 (excellent).

A complete randomized design was used that included 10 observations for each ethephon treatment. Data were analyzed using SAS (SAS Institute, Cary, NC) mixed model procedure (PROC MIXED) for analysis of variance with means and SE presented. Although similar patterns in growth responses were observed for both years, data were not pooled and were analyzed separately for each year because of differences in time of data collection and cutting harvest. Data from the 2003 experiment are presented and are representative of both years.

\section{Results}

Dianthus caryophyllus 'Cinnamon Red Hots'. Ethephon did not cause flower bud abortion for Dianthus 'Cinnamon Red Hots' at any of the rates tested (data not shown). Ethephon application inhibited internode length severely and resulted in deformed growth and elicited phytotoxic symptoms, including leaf margin necrosis.

Coreopsis verticillata 'Moonbeam'. The statistical similarity between the two control treatments (ethephon application at $0 \mathrm{mg} \cdot \mathrm{L}^{-1}$ and ethephon application plus water spray at $0 \mathrm{mg} \cdot \mathrm{L}^{-1}$ ) allowed data to be pooled for $\mathrm{SL}$, $\mathrm{PS}$, and number of $\mathrm{VC}$ and $\mathrm{RC}$ harvested. However, the number of RB was significantly different between these treatments, and data were not pooled for this parameter.

Repeated ethephon applications significantly inhibited SL for plants. For example, between weeks 5 and 7, shoot elongation in control plants was $6.7 \mathrm{~cm}$ compared with 1.6 and $2.4 \mathrm{~cm}$ for plants receiving weekly

Table 1. List of herbaceous perennial species, plug sizes, and cutting harvest dates for ethephon-treated plants.

\begin{tabular}{lccc}
\hline Perennial plant species & Plug size & $\begin{array}{c}\text { Cutting } \\
\text { harvest date }\end{array}$ & $\begin{array}{c}\text { Weeks after } \\
\text { first ethephon } \\
\text { application }^{z}\end{array}$ \\
\hline Coreopsis verticillata 'Moonbeam' & 32-cell $(180 \mathrm{~mL})$ & 1 Apr. \\
17 Apr. & 2 \\
Dianthus caryophyllus 'Cinnamon Red Hots' & 84-cell $(20 \mathrm{~mL})$ & 9 May & 7 \\
Veronica longifolia 'Sunny Border Blue' & 72-cell $(35 \mathrm{~mL})$ & 29 Apr. & 2 \\
Veronica longifolia 'Sunny Border Blue'y & 72-cell $(35 \mathrm{~mL})$ & 1 Apr. & 2 \\
& & 22 Apr. & 5 \\
\end{tabular}

${ }^{\mathrm{z}}$ Ethephon was first applied on 18 Mar. 2003.

yPlants were cooled for 8 weeks at $5{ }^{\circ} \mathrm{C}$ before the first ethephon application on 13 May 2003.
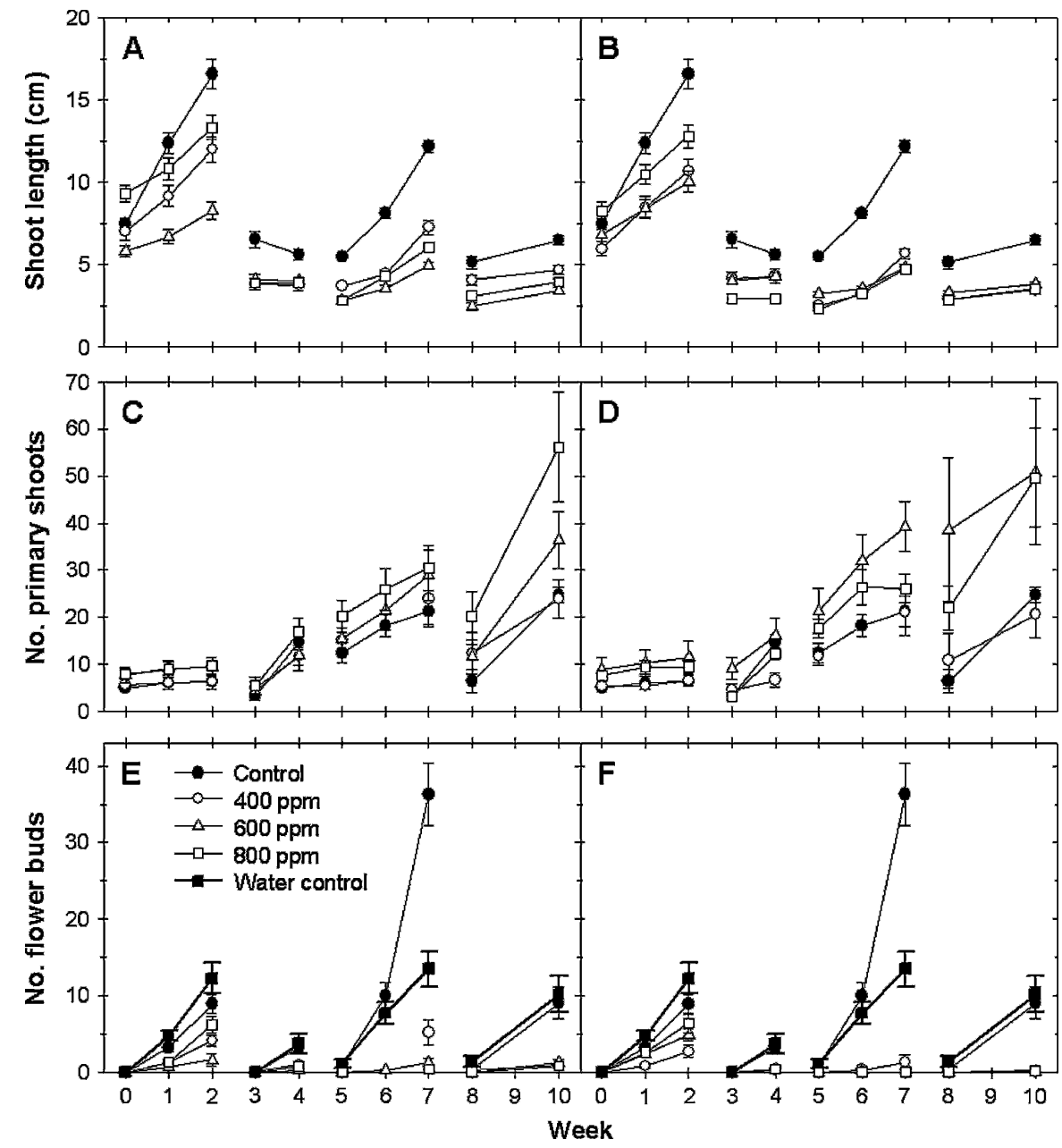

Fig. 1. The effect of biweekly $(\mathbf{A}, \mathbf{C}, \mathbf{E})$ and weekly $(\mathbf{B}, \mathbf{D}, \mathbf{F})$ foliar spray applications of ethephon on shoot length, number of primary shoots, and number of flower buds in Coreopsis verticillata 'Moonbeam' during Year 2. Cuttings were harvested 2, 4, and 7 weeks after the onset of treatments. Legend in $\mathbf{E}$ applies to all figures. Error bars represent SE. 
ethephon applications of 600 and $800 \mathrm{mg} \cdot \mathrm{L}^{-1}$, respectively (Fig. 1). However, the inhibition of shoot elongation was not indicative of a reduction of total plant growth. Rather, plants that received ethephon at $800 \mathrm{mg} \cdot \mathrm{L}^{-1}$ biweekly and weekly developed a significantly greater number of shoots (average of 31 and 26, respectively) compared with control plants (average 21) between weeks 5 and 7. By week 10, control plants produced 25 shoots, whereas plants receiving biweekly ethephon applications of $800 \mathrm{mg} \cdot \mathrm{L}^{-1}$ or weekly applications of 600 or $800 \mathrm{mg} \cdot \mathrm{L}^{-1}$ had at least twice as many shoots $(56,51$, or 50 , respectively). In addition, plants that received applications of ethephon at 600 and $800 \mathrm{mg} \cdot \mathrm{L}^{-1}$ consistently produced fewer flower buds compared with control plants (Fig. 1). For example, at week 7, control plants had developed 14 or more floral buds, whereas plants treated with ethephon at 600 $\mathrm{mg} \cdot \mathrm{L}^{-1}$ had developed fewer than two flower buds per plant.

The number of harvested VC was greatest for plants that received biweekly or weekly applications of ethephon at 600 or 800 $\mathrm{mg} \cdot \mathrm{L}^{-1}$ (Fig. 2A). The average number of VC per plant from all three harvests was 16 for the control treatments compared with 34 or 35 with biweekly ethephon treatments at 600 or $800 \mathrm{mg} \cdot \mathrm{L}^{-1}$, respectively, and 40 or 28 with weekly applications at 600 or 800 $\mathrm{mg} \cdot \mathrm{L}^{-1}$, respectively. In contrast, RC number was greatest for control plants with an average of 26 per plant from the three harvests (Fig. 2B). Plants treated with ethephon produced a sum of 12 or less $\mathrm{RC}$ per plant during the 10 weeks of the experiment regardless of rate and application frequency. Therefore, $62 \%$ of the cuttings harvested from control Coreopsis plants were reproductive, whereas less than $22 \%$ of cuttings harvested from plants treated with ethephon at 600 or 800 $\mathrm{mg} \cdot \mathrm{L}^{-1}$ were reproductive.

Cuttings from ethephon-treated plants had thicker stems, were shorter, and had fewer flower buds in the propagation house than untreated plants (data not shown). On the subjective performance scale of 1 to 6 ( 6 being excellent), cuttings from control plants were often rated between 1 and 3 and averaged 1.8, whereas cuttings from ethephon-treated plants averaged 3.2 to 4.2 (Table 2). The DW of cuttings taken from controls was similar to or greater than that from plants treated with ethephon (Fig. 3A). Cuttings taken at the second harvest had a lower DW in most treatments than cuttings from the first and third harvests. At the third harvest, when cutting number was greatest, the DW of control cuttings was $47 \%$ or more greater than that of cuttings treated with ethephon.

Veronica longifolia 'Sunny Border Blue'. Collected data from the control treatments (with and without water spray) were not statistically different, and thus data were pooled for all measured variables. Cooled Veronica control plants exhibited trends in measured variables similar to those of noncooled plants, although there was a signifi-

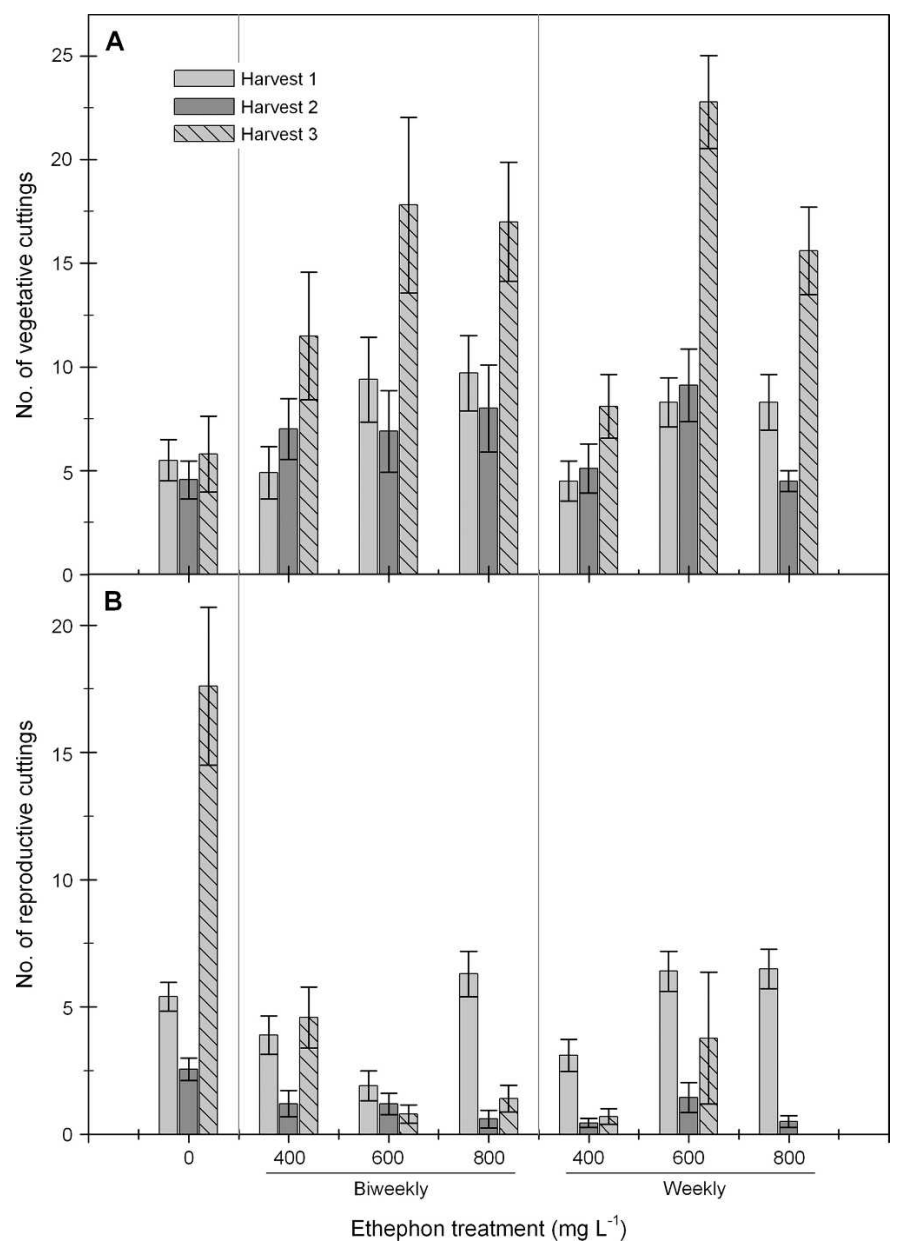

Fig. 2. Effects of ethephon on the average number of vegetative (A) and reproductive (B) cuttings per plant at each cutting harvest date of Coreopsis verticillata 'Moonbeam' during Year 2. Error bars represent SE.

Table 2. Effect of ethephon spray application on cutting quality rating of Coreopsis verticillata 'Moonbeam' and cooled and noncooled Veronica longiflora 'Sunny Border Blue'.

\begin{tabular}{|c|c|c|c|c|}
\hline Treatment $\left(\mathrm{mg} \cdot \mathrm{L}^{-1}\right)$ & Harvest 1 & Harvest 2 & Harvest 3 & Avg \\
\hline \multicolumn{5}{|c|}{ Coreopsis } \\
\hline 0 (control) & 2.2 & 2.1 & 1.0 & 1.8 \\
\hline 0 Water spray (control) & 3.4 & 2.5 & 1.8 & 2.6 \\
\hline 400 Biweekly & 2.9 & 3.7 & 3.0 & 3.2 \\
\hline 600 Biweekly & 4.1 & 4.7 & 3.6 & 4.1 \\
\hline 800 Biweekly & 3.6 & 4.3 & 4.2 & 4.0 \\
\hline 400 Weekly & 3.7 & 4.3 & 3.9 & 4.0 \\
\hline 600 Weekly & 2.7 & 4.3 & 3.9 & 3.6 \\
\hline 800 Weekly & 3.9 & 5.2 & 3.6 & 4.2 \\
\hline \multicolumn{5}{|c|}{ Veronica (noncooled) } \\
\hline 0 (control) & $\mathrm{y}^{\mathrm{y}}$ & 4.9 & - & - \\
\hline 0 Water spray (control) & - & 4.5 & - & - \\
\hline 400 Biweekly & 4.3 & 4.5 & - & - \\
\hline 600 Biweekly & - & 4.1 & - & - \\
\hline 800 Biweekly & - & 3.8 & - & - \\
\hline 400 Weekly & 4.1 & 4.5 & - & - \\
\hline 600 Weekly & 5.6 & 4.1 & - & - \\
\hline 800 Weekly & - & 3.8 & - & - \\
\hline \multicolumn{5}{|c|}{ Veronica $(\text { cooled })^{\mathrm{x}}$} \\
\hline 0 (control) & 3.9 & 4.3 & - & 4.1 \\
\hline 0 Water spray (control) & 3.6 & 4.7 & - & 4.2 \\
\hline 400 Biweekly & 3.7 & 4.1 & - & 3.9 \\
\hline 600 Biweekly & 4.2 & 3.9 & - & 4.1 \\
\hline 800 Biweekly & 3.6 & 4.5 & - & 4.1 \\
\hline 400 Weekly & 3.5 & 3.9 & - & 3.7 \\
\hline 600 Weekly & 2.9 & 4.4 & - & 3.7 \\
\hline 800 Weekly & 2.8 & 3.6 & - & 3.2 \\
\hline
\end{tabular}

${ }^{\mathrm{z}}$ Quality ratings were subjectively assigned to each cutting according to cutting height, number of floral buds per cutting, and rooting by using a scale from 1 (poor) to 6 (excellent).

yata not available.

xPlants were cooled at $5{ }^{\circ} \mathrm{C}$ for 8 weeks before ethephon applications. 


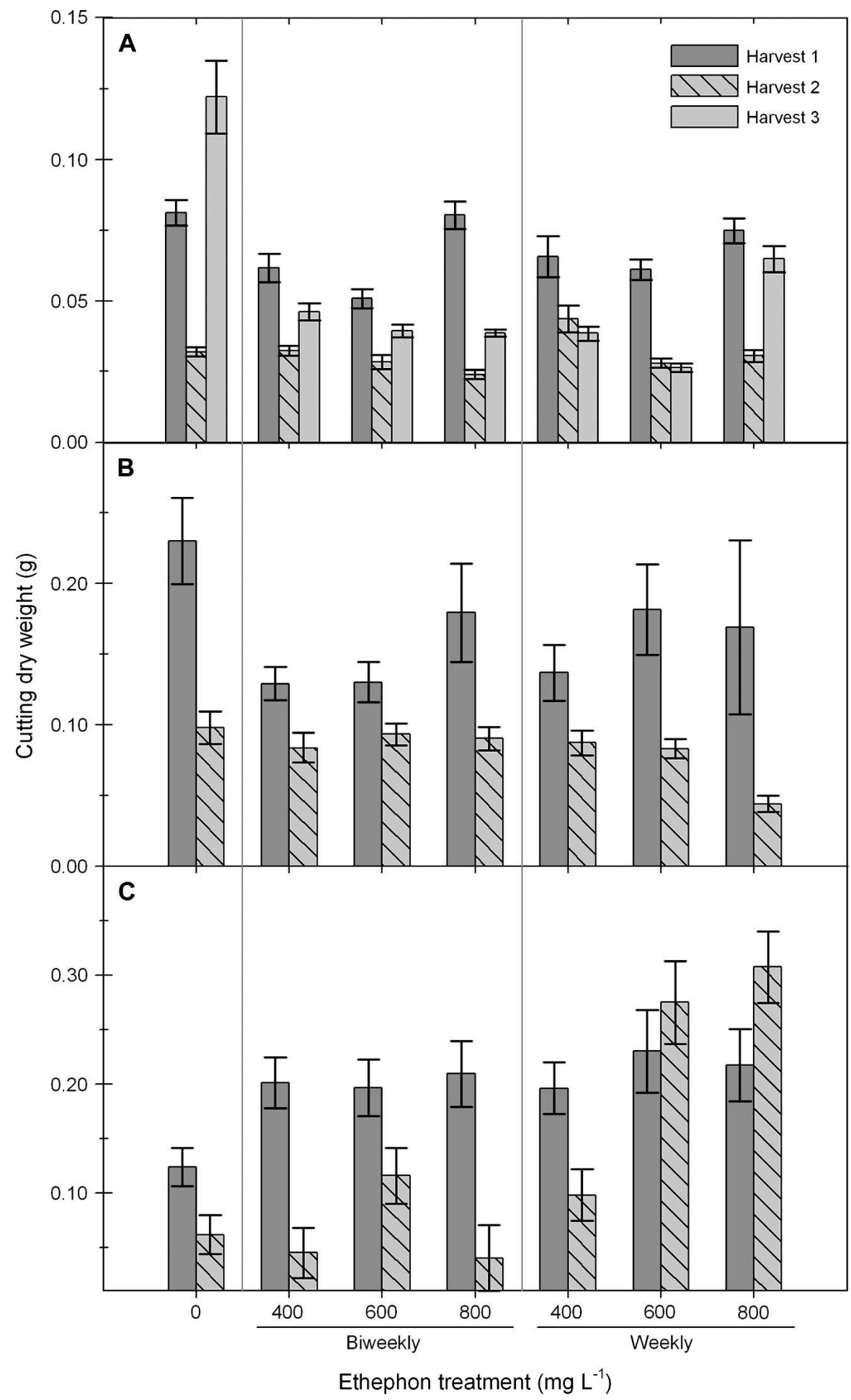

Fig. 3. The effect of ethephon application on cutting dry weight in Coreopsis verticillata 'Moonbeam' (A), noncooled Veronica longifolia 'Sunny Border Blue' $(\mathbf{B})$, and cooled ( 8 weeks at $5{ }^{\circ} \mathrm{C}$, before ethephon application) Veronica longifolia 'Sunny Border Blue' (C) during Year 2. Error bars represent SE.

cant difference in the reproductive status for the cooled and noncooled plants.

During the first 2 weeks of treatments and before the first harvest, ethephon had little impact on vegetative growth of Veron$i c a$, whether plants had been cooled or not (Fig. 4). SL increased from $\approx 4 \mathrm{~cm}$ to $10 \mathrm{~cm}$, and PS remained similar in all treatments and averaged 1.5 to 2.5 per plant. After the first harvest, cooled plants generally had a also increased PS after the second harvest; PS increased by 7.2 from weeks 7 to 10 in control plants and increased by 16.1 and 23.0 when ethephon was applied biweekly or weekly at $800 \mathrm{mg} \cdot \mathrm{L}^{-1}$, respectively.

Similar trends were observed in cooled Veronica stock plants; SL was increasingly inhibited and PS increased as the applied rate and frequency of ethephon increased. For example, biweekly applications of ethephon at $400 \mathrm{mg} \cdot \mathrm{L}^{-1}$ inhibited SL by $70 \%$ and $54 \%$ when measured 3 weeks after the first and second harvests, respectively. In addition, PS of plants sprayed with biweekly or weekly applications of ethephon at $800 \mathrm{mg} \cdot \mathrm{L}^{-1}$ was more than twice that of control plants at week 10 . However, plant foliage of cooled Veronica exhibited phytotoxic symptoms (i.e., necrotic tissue) at week 4 when ethephon applications of 600 and $800 \mathrm{mg} \cdot \mathrm{L}^{-1}$ were applied weekly. Cuttings from these two treatments were difficult to harvest because of severely reduced shoot size.

Veronica plants that were not cooled had no RB before week 10, when actual numerical differences were 3 or less, and thus no $\mathrm{RC}$ were harvested (data not shown). Regardless of treatment, no visible RB had formed on cooled plants during the first 4 weeks of the experiment, and biweekly applications of ethephon at greater than $400 \mathrm{mg} \cdot \mathrm{L}^{-1}$ consistently kept the number of RB one or less for the first 9 weeks (data not shown). The number of VC harvested per noncooled plant significantly increased as ethephon concentration increased with the greatest number of cuttings harvested from treatment plants at 600 and $800 \mathrm{mg} \cdot \mathrm{L}^{-1}$ at the second harvest interval (Fig. 5A). In cooled Veronica, a similar number of cuttings were harvested in all treatments at the first harvest event (Fig. $5 \mathrm{~B})$. At the second harvest event, generally more cuttings were harvested from plants treated with ethephon compared with those not treated.

The quality of cuttings taken from control plants was similar to, or slightly higher than, that of cuttings taken from plants treated with ethephon (Table 2). In general, as the rate of ethephon application increased, the subjective quality of cuttings decreased, from $\approx 4.7$ (mean of two control treatments) to 3.8. In general, cuttings were of lower quality because ethephon reduced cutting length and reduced rooting, and phytotoxicity was evident on the foliage. There were no $\mathrm{RC}$ at the first cutting harvest from any noncooled ethephon plants or at the second harvest from cooled plants that received weekly ethephon applications of 600 or $800 \mathrm{mg} \cdot \mathrm{L}^{-1}$ (data not shown).

For noncooled Veronica plants, cuttings from control plants had the greatest DW at the first harvest interval (Fig. 3B). The DW of cuttings at the second harvest was significantly less than at the first harvest for control and ethephon-treated plants. The highest DWs at both harvest intervals were from cooled plants treated with ethephon weekly at 600 and $800 \mathrm{mg} \cdot \mathrm{L}^{-1}$ (Fig. 3C). 

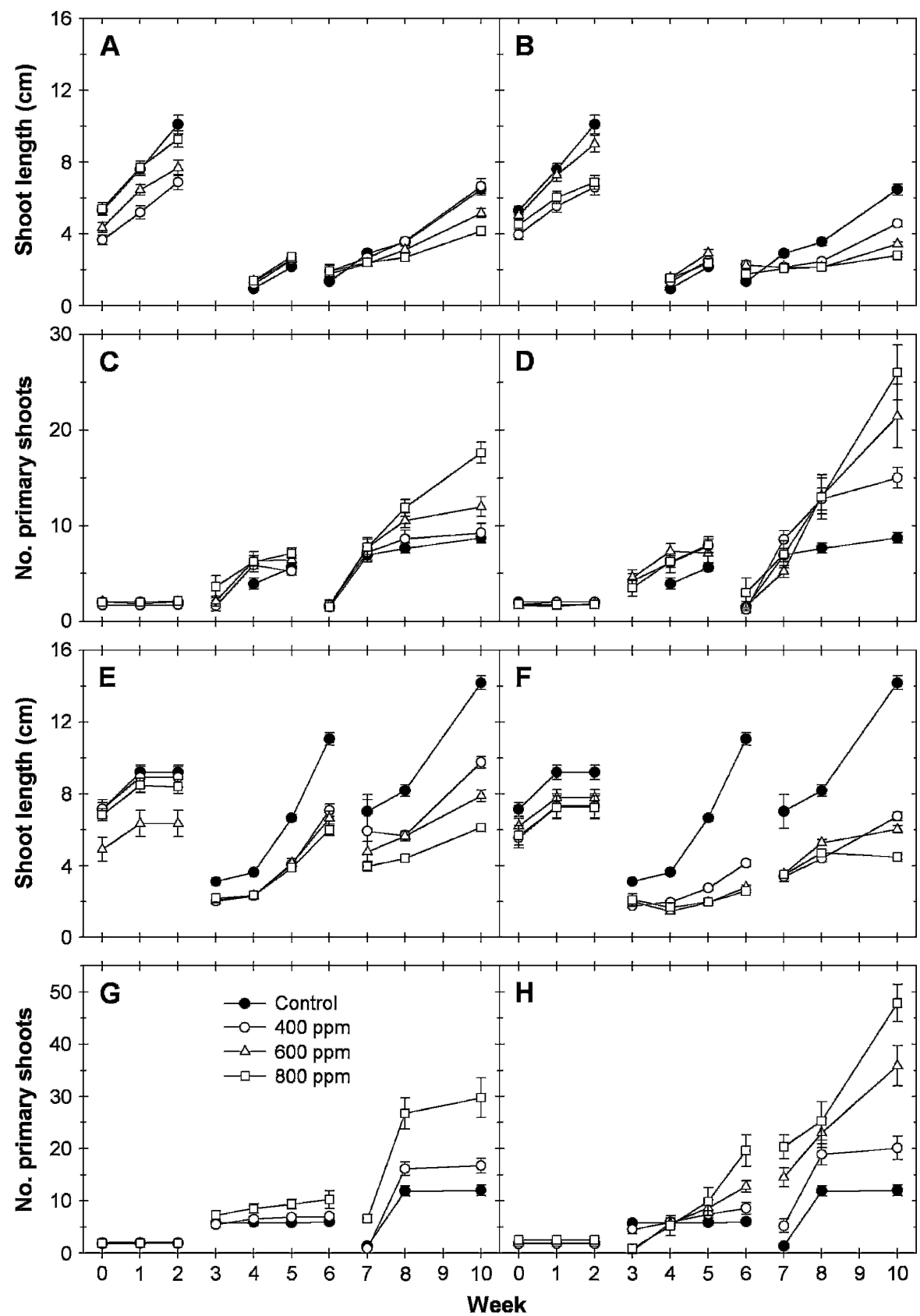

Fig. 4. The effect of biweekly $(\mathbf{A}, \mathbf{C}, \mathbf{E}, \mathbf{G})$ and weekly $(\mathbf{B}, \mathbf{D}, \mathbf{F}, \mathbf{H})$ foliar spray applications of ethephon on shoot length and number of primary shoots in noncooled (A-D) and cooled $(\mathbf{E}-\mathbf{H})$ Veronica longifolia 'Sunny Border Blue' during Year 2. Cuttings were harvested 2 and 6 weeks after the onset of treatments. Legend in E applies to all figures. Error bars represent SE.

\section{Discussion}

The effect of ethephon on herbaceous plants is species-dependent. A common rate of ethephon used at commercial greenhouse operations is $500 \mathrm{mg} \cdot \mathrm{L}^{-1}$. Our work shows that Coreopsis, a qualitative long-day plant, can be maintained as a vegetative stock plant by biweekly ethephon applications at $600 \mathrm{mg} \cdot \mathrm{L}^{-1}$. Veronica, a day-neutral plant that requires a cold treatment for flowering, responded to ethephon at $400 \mathrm{mg} \cdot \mathrm{L}^{-1}$ weekly to maintain vegetative growth. The number of PS increased the most in Coreopsis and Veronica during the experimental interval with weekly ethephon concentrations of 600 and $800 \mathrm{mg} \cdot \mathrm{L}^{-1}$. This promotion of branching from ethephon has been reported in other crops, including geranium (Pelargonium $\times$ hortorum L.H. Bail.) (Carpenter and Carlson, 1970; Tayama and Carver, 1990). Although ethephon increased branching in Dianthus 'Cinnamon Red Hots', it did not affect floral development. A higher rate of ethephon may abort flowers of Dianthus, but the inhibition of extension growth at the rates tested made cutting harvest difficult. Similarly, foliar applications of ethephon at 1200 to 4800 $\mathrm{mg} \cdot \mathrm{L}^{-1}$ inhibited flowering of purple velvet plants [Gynura aurantiaca (Blume) DC.], but also stunted plants and made cutting harvest impossible (Pallez and Dole, 2001).
The species-specific sensitivity to ethephon has been reported with other herbaceous crops. For example, heliotrope (Heliotropium arborescens L.) requires concentrations greater than $500 \mathrm{mg} \cdot \mathrm{L}^{-1}$ to abort flower buds, double impatiens (I. walleriana Hook.) require only 200 to $300 \mathrm{mg} \cdot \mathrm{L}^{-1}$ to increase branching and inhibit reproductive growth, and trailing snapdragon (Antirrhinum majus L.) did not respond to ethephon at $1000 \mathrm{mg} \cdot \mathrm{L}^{-1}$ (Konjoian, 1999a, 1999b; Starman et al., 2004). Collectively, our work and previous studies substantiate that a single application rate cannot be used on a variety of perennial and annual plants.

Application of ethephon can be phytotoxic to plants depending primarily on the rate used and plant species. In this experiment, rates greater than $600 \mathrm{mg} \cdot \mathrm{L}^{-1}$ biweekly damaged Veronica leaves, which is below the phytotoxic threshold in other plants such as Monarda didyma L. in which an ethephon treatment of $1000 \mathrm{mg} \cdot \mathrm{L}^{-1}$ caused foliar necrosis (Hayashi et al., 2001). The variance in response could be based on chemical, plant, and environmental interactions (Beaudry and Kays, 1988). A better understanding of these responses is essential for developing industry recommendations because of the variation in plant responses, and thus commercial production schedules, to the environment.

Successful use of ethephon also depends on the quality and condition of the cutting received (Konjoian, 1993). In these experiments, the intervals at which ethephon was sprayed affected the regrowth performance after cuttings were harvested. The continued stress of ethephon application within 1 week of cutting harvests resulted in deformed vegetative growth and excessive inhibition of stem extension, particularly in Dianthus and Veronica, which was not suitable for cuttings. Thus, the recommendation to allow 1 to 2 weeks before and after a cutting event before resuming ethephon application (Konjoian, 1994b) should be followed. When cuttings were harvested and propagated, there was no apparent residual effect of ethephon during propagation.

Temperature, relative humidity, and solution $\mathrm{pH}$ have been reported to have a substantial influence on responses to ethephon. In addition, light intensity can also have significant effects on plant growth and responses to ethephon (Runkle and Heins, 2004; Thomas and Vince-Prue, 1997). The difference in the DLI between noncooled and cooled Veronica plants varied by as much as $7 \mathrm{~mol} \cdot \mathrm{m}^{-2} \cdot \mathrm{d}^{-1}$ (data not shown). A higher DLI can increase branching and thus the number of cuttings harvested from each plant. However, in our studies, cooled Veronica plants grown under a greater DLI did not have more $\mathrm{VC}$ than noncooled Veronica plants.

In our work, the number of RB was reduced in Coreopsis by $100 \%$ with weekly ethephon applications at $800 \mathrm{mg} \cdot \mathrm{L}^{-1}$. Ethephon also decreased RB by $88 \%$ in cooled Veronica plants. Collectively, these data support previous work in which ethephon 1) reduced the number of inflorescences in 


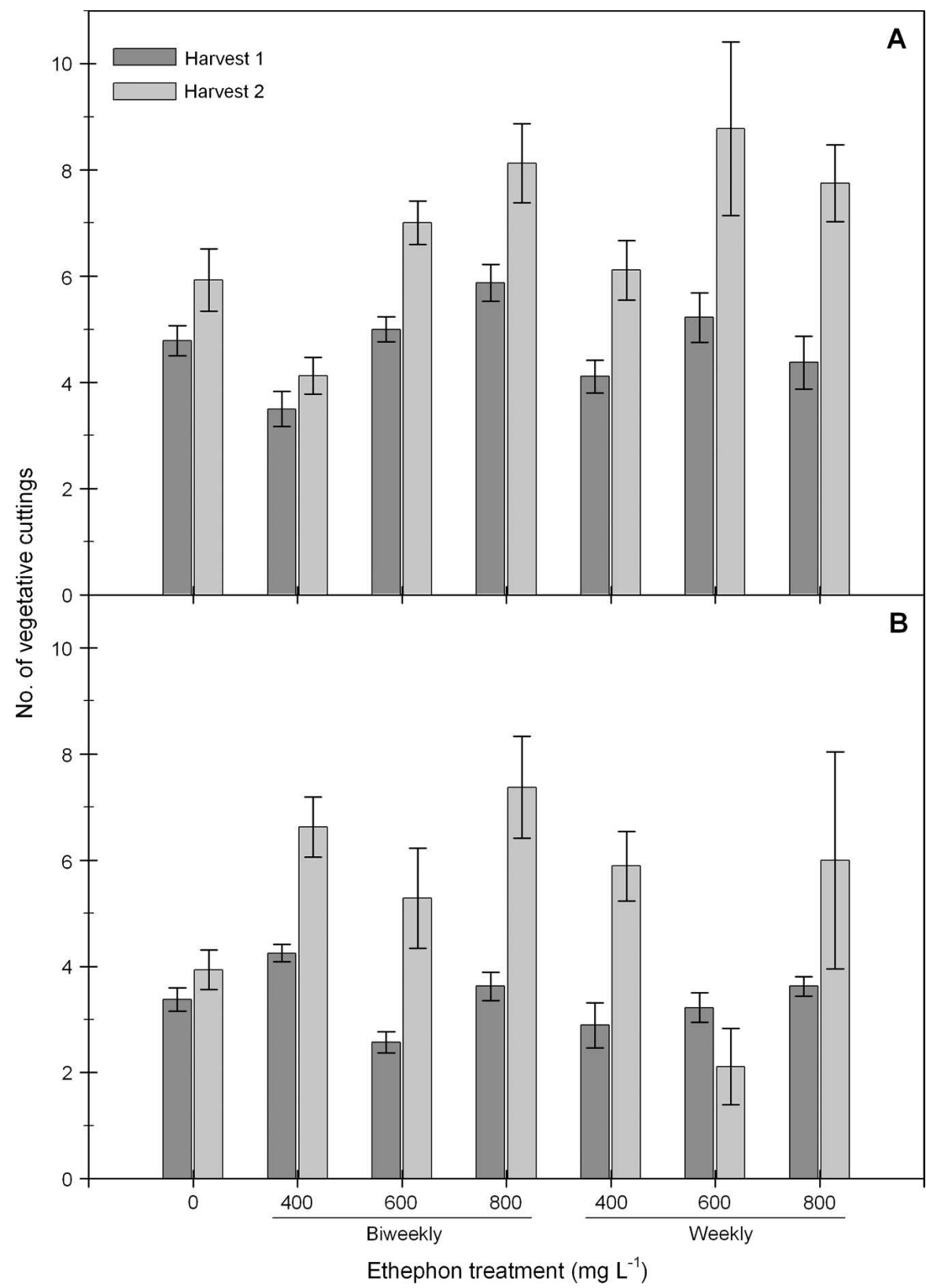

Fig. 5. Effects of ethephon on the average number of Veronica longifolia 'Sunny Border Blue' cuttings taken from noncooled (A) and cooled (B) plants at each cutting harvest date during Year 2. Error bars represent SE.

Hebe $\times$ franciscana (Eastw.) Souster 'Variegata' plants (Kristensen and Adreansen, 1988); 2) delayed flowering of the first and second inflorescences by 5 to $10 \mathrm{~d}$, respectively, in seed-propagated geraniums sprayed with ethephon at $1000 \mathrm{mg} \cdot \mathrm{L}^{-1}$ (Carpenter and Carlson, 1970); and 3) delayed flowering in the perennials Achillea millefolium L., Echinacea purpurea Moench., Monarda, and Physostegia virginiana Bentham by 2, 6, 7, and $9 \mathrm{~d}$, respectively, with three ethephon applications at $1000 \mathrm{mg} \cdot \mathrm{L}^{-1}$ (Hayashi et al., 2001).

The objective of this study was to determine whether ethephon application can improve stock plant management in perennials, phon applied to Dianthus did not abort flower buds at the rates and frequencies used, severely stunted internode extension growth, and caused deformed growth and marginal leaf necrosis.

\section{Literature Cited}

Beaudry, R.M. and S.J. Kays. 1988. Application of ethylene-releasing compounds in agriculture, p. 127-155. In: P.M. Neumann (ed.). Plant growth and leaf-applied chemicals. CRC Press, Boca Raton, FL.

Bunt, A.C. and K.E. Cockshull. 1985. Dianthus caryophyllus, p. 433-440. In: A.H. Halevy (ed.). CRC handbook of flowering. CRC Press, Boca Raton, FL.

Carpenter, W.J. and W.H. Carlson. 1970. The influence of growth regulators and temperature on flowering of seed propagated geraniums. HortScience 5:183-184.

Hamaker, C., R.D. Heins, A.C. Cameron, and W.H Carlson. 2000. Coreopsis verticillata. In: Firing up perennials: The 2000 edition. GG Plus, Willoughby, $\mathrm{OH}$.

Hamrick, D. 2003. Ball redbook. 17th ed., vol. 2. Ball Publishing, Batavia, IL.

Hayashi, T., R.D. Heins, A.C. Cameron, and W.H Carlson. 2001. Ethephon influences flowering, height, and branching in several herbaceous perennials. Scientia Hort. 91:305-324.

Konjoian, P. 1993. 1993 Garden mum research. Konjoian's Floriculture Education Services, Inc., Andover, MA. p. 3.

Konjoian, P. 1994a. The economics of Florel use: Part 1. Konjoian's Floriculture Education Services, Inc., Andover, MA. p. 4.

Konjoian, P. 1994b. Florel treatment of stock plants: Where are we heading? Konjoian's Floriculture Education Services, Inc., Andover, MA. p. 8.

Konjoian, P. 1999a. Expanded gFlorel label approved by EPA! Konjoian's Floriculture Education Services, Inc., Andover, MA. p. 4.

Konjoian, P. 1999b. 1999 Ecke cooperative project: The use of Florel on double impatiens. Konjoian's Floriculture Education Services, Inc., Andover, MA. p. 2.

Kristensen, L.N. and E. Adreansen. 1988. Growth and flowering in Hebe $\times$ franciscana "Variagata' treated with plant growth regulators. Scientia Hort. 36:139-149.

Pallez, L.C. and J.M. Dole. 2001. Maintaining vegetative potted purple velvet plants. HortTechnology 11:590-595.

Runkle, E. and R. Heins. 2004. Florel on summer production of pansy. Greenhouse Product News 14:36-38.

Runkle, E.S., R.D. Heins, A.C. Cameron, and W.H. Carlson. 1998. Flowering of herbaceous perennials under various night interruption and cyclic lighting treatments. HortScience 33:672-677.

Starman, T.W., M.C. Robinson, and K.L. Eixmann. 2004. Efficacy of ethephon on vegetative annuals. HortTechnology 14:83-87.

Tayama, H.K. and S.A. Carver. 1990. Zonal geranium growth and flowering responses to six growth regulators. HortScience 25:82-83.

Thomas, B. and D. Vince-Prue. 1997. Photoperiodism in plants. 2nd ed. Academic Press, San Diego.

Whitman, C.D., D. Tschirhart, D. Joeright, and R. Heins. 2000. New Guinea impatiens: Flowers on time. Greenhouse Grower 18:48-60. 